


\section{Online folyóirat}

Szerkesztette: VÁGÁNY Judit Bernadett, PhD - FENYVESI Éva, PhD

Borító: FLOW PR

Kiadja: Budapesti Gazdasági Egyetem, Kereskedelmi, Vendéglátóipari és Idegenforgalmi Kar, Közgazdasági és Üzleti Tudományok Tanszék

Felelős kiadó: FENYVESI Éva, PhD

a Közgazdasági és Üzleti Tudományok Tanszék vezetője

ISSN 2630-886X

2019. 


\title{
A KÖZPONTI KÖLTSÉGVETÉSI SZERVEK ELLENŐRZÉSÉNEK INNOVÁCIÓS TAPASZTALATAI AZ INFORMÁCIÓS ADATSZOLGÁLTATÁSI (KGR-K11) RENDSZER FEJLESZTÉSE ÁLTAL
}

\author{
INNOVATION EXPERIENCE OF CONTROL OF \\ BUDGETARY INSTITUTIONS BY DEVELOPMENT OF \\ THE INFORMATION DATA SERVICE (KGR-K11) SYSTEM
}

BELOVECZ Mária - HIDEG ISTVÁNNÉ FIATAL Szilvia - HALMOSI Tímea

Kulcsszavak: Államkincstár, KGR-K11, kö̈ponti kältségvetés, belsö ellenörzés Keywords: Hungarian State Treasury, KGR-K11, national budget, internal audit

JEL kód: $G 2$ 


\section{ÖSSZEFOGLALÓ}

Egy ország müködéséhez. elengedhetetlen a költségvetés megtervezése és annak végrehajtásának ellenörzése. Ez fontos feladat egy állam számára, hiszen ezen keresz̨ül valósitja meg állami funkcióit,

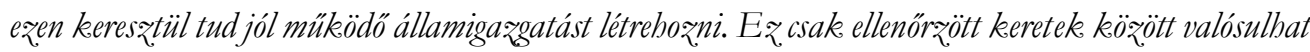
meg, úgynevezett kincstári rendszerben. A Magyar Allamkincstár végzi az állami költségvetés pénzforgalmának lebonyolitását, valamint ö folytatja le az állambáztartás belsö ellenörzését.

Ebben a tanulmányban az. Allamkincstár Költségvetési Fejezetek. Föosztályának, ezen belül is a Költségvetési Információs Osztály feladatainak a bemutatása a célunk. Az általa végzett ellenörzéseknek, továbbá az ellenörzések adataiból képezhetö információk elkészítésének a végrehajtása a mostani keretek közö̈tt eléggé újszerü, valamint még jelenleg is fejlesztés alatt áll. A feladatuk. végrehajtásához használt rendszer, a KGR-K11. A rendszer adattábláinak hasonló szuerkezete egyszerübbé teszi, hogy a köztük lévö összefüggések is a rendszerbe ágyazottak legyenek. Ennek köszönhetöen az éves költségvetési beszámoló adatszolgáltatásai is hamarabb elkészülnek, igy a zárszámadás elkészitését sem késleltetik.

Az elektronikus adatszolgáltatás lehetöségének megteremtése az adatáramlást is felgyorsitotta. A KGRK11 rendszer az adatszolgáltatások pontosságát és az ellenörzések hatékonyságát nagymértékeben megnövelte annake ellenére, hogy fejlödése folyamatos.

\section{SUMMARY}

Necessary for the functioning of a country the planning and monitoring the implementation of the budget is an important task for the state. The state so realizes its functions and creates a well-functioning state administration. This can only happen in a controlled framework, in ,treasury system”. In 1996, when the Hungarian State Treasury was set up by the National Assembly, which currently manages and audits national budgetary transactions, and also audits financial transactions conducted by other budgetary institutions The Hungarian State Treasury is a self-managed central budget department with independent legal personality.

The present study focuses on the operation of the Budgetary Information Office. The framework for the audits conducted and for processing and analyzing the data generated is relatively new and is still being developed. In order to achieve high efficiency of both transactions and auditing, and meet the standards stipulated, high level developments have been implemented in the informatics background of such operations. The wide variety of accounting softwares used by different budgetary institutions still poses some difficulty for the informatics systems developers and users of KGR-K11, as data provided by budgetary institutions all over the country need to be processed in a single framework in order to balance treasury and ledger accounts. However, as a result, annual budget reports are now conducted in a timely manner.

Electronic data sending has accelerated the flow of data. On the whole, data are provided and audited faster and more efficiently, even though the KGR-K11 system is still being developed. 


\section{BEVEZETÖ}

A hazai államháztartási ellenőrzés 1989-ben indult fejlődésnek az Állami Számvevőszék létrejöttével. Majd 1995-ben a Parlament létrehozta a Magyar Államkincstárt a belső kontroll végrehajtójaként, az államháztartási finanszírozás csökkentése, és a pénzfelhasználás áttekinthetőbbé tétele érdekében. Azóta a Magyar Államkincstár végzi az állami költségvetés pénzforgalmának lebonyolítását, valamint ő folytatja le az államháztartás belső ellenőrzését is. Ennek megvalósításának alapjául szolgál az Államháztartási törvény, melyet először 1992-ben alkottak meg (1992. évi XXXVIII. törvény), és amit azóta az Európai Uniós jogszabályokhoz igazítottak. A jelenleg hatályos formája az államháztartásról szóló 2011. évi CXCV. törvény, kiegészítve a végrehajtásában segítő 368/2011. (XII. 31.) Kormányrendelettel. A 2011. évi CXCV. törvény (röviden: Áht.) célja, hogy az általa kialakított folyamatrendszerben a költségvetési szervek a tevékenységüket és a gazdálkodásukat a törvényeknek megfelelően lássák el elszámolási kötelezettségük végrehajtásával együtt, amivel megvédhetik erőforrásaikat a veszteségektől, melyek a gazdálkodás nem megfelelő végrehajtásából adódnak.

A Magyar Államkincstárt 1996-ban a közfeladatok szabályozott, hatékony, eredményes pénzellátása érdekében a közfeladatok olcsóbb finanszírozása, a pénzgazdálkodás centralizálása érdekében alapították önálló jogi személyiséggel rendelkező, önállóan gazdálkodó központi költségvetési szervként. „Az alaptevékenységként ellátott feladatok közül meghatározó a kincstári előirányzat-gazdálkodás, finanszírozás és a pénzforgalmi számlavezetés rendszere, ezzel kapcsolatos ellenőrzések ellátása, az információgyűjtési és adatszolgáltatási kötelezettségek teljesítése.” (ARADI et al., 2004 p. 23.) A költségvetési törvényben meghatározott költségvetési kiadásoknak megfelelően a Kincstár ún. előirányzat-felhasználási keretet bocsát az államháztartás intézményeinek meghatározott, ún. kincstári körbe tartozó intézmények (az államháztartás központi alrendszerébe tartozó jogi személyek és előirányzatok) részére. Ezen előirányzatok módosításait és ezen előirányzat módosítások jogszabályoknak megfelelő végrehajtását ellenőrzi, illetve a központi költségvetési szervek és a fejezeti kezelésű előirányzatok finanszírozását végzi a Kincstár azzal együtt, hogy vezeti ezek pénzforgalmi számláit. A pénzforgalom lebonyolítására a Kincstár a Magyar Nemzeti Banknál pénzforgalmi számlával, úgynevezett kincstári egységes számlával rendelkezik, illetve deviza számlát is nyithat. (Aradi et al., 2004 p. 23) A kincstári kör egymás közötti fizetéseinek elszámolása átvezetéssel történik.

Ezeken túl a Kincstár múködteti az országos támogatási és monitoring rendszert a központi költségvetésből származó pályázatok alapján folyósított támogatások nyomon követése érdekében, valamint szabályszerűségi pénzügyi ellenőrzést végez az államháztartás önkormányzati alrendszerében és végzi a központi illetményszámfejtést.

A Kincstáron belül a Fejezeti Főosztály néven létrehozott egység a Kincstár feladatai közül a központi költségvetési szerveket és a fejezeti kezelésű előirányzatokat érintő többek között - előirányzat-módosítások ellenőrzését, végrehajtását, finanszírozását, a 
költségvetési pozíció előrejelzését és a likviditás menedzselését végzi. Továbbá meghatározott adatszolgáltatások, elemzések, statisztikai számvetések elkészítését a felettes szervek, többek között a Központi Statisztikai Hivatal, a Pénzügyminisztérium, a Magyar Nemzeti Bank felé, illetve külső megkeresésre közérdekű adatszolgáltatást végez. A Kincstár által ellátott ellenőrzési feladatok legfőbb területe a költségvetés realizálásának pénzügyi lebonyolítása, illetve az ehhez kapcsolódó nyilvántartási feladatok ellátása segítségével ezek ellenőrzése. Az Áht. realizálásában a kormányrendeleti szint már konkrétan megfogalmazza a költségvetési szervek belső kontrollrendszerének kialakításával és működtetésével kapcsolatos tennivalókat a költségvetési szerv vezetője számára.

A Költségvetési Fejezetek Főosztályának, ezen belül is részletesebben a Költségvetési Információs Osztály feladatainak bemutatása a célunk, mivel ezeknek az ellenőrzéseknek, továbbá az ellenőrzések adataiból képezhető információk elkészítésének és az általuk megvalósuló tájékoztatási feladatoknak a végrehajtása a jelenlegi keretek között még eléggé újszerű az államháztartás rendszerében, ezért folyamatos fejlesztés alatt áll. Az elmúlt négy évben a feladatok megfelelő végrehajtása érdekében kitüzött célok elérését biztosító informatikai fejlesztések magas színvonalon folynak. Így a folyamatok letisztultabbak lettek, ezáltal nőtt a végrehajtás és az ellenőrzés hatékonysága. Célunk annak a felderítése, hogy hogyan lehetne ezeket a feladatokat még hatékonyabban végrehajtani.

\section{SZAKIRODALOMFELDOLGOZÁS}

\section{A Magyar Államkincstár bemutatása}

„A Magyar Államkincstár (Hungarian State Treasury, Ungarisches Schatzamt, Trésor Public de la Hongrie) önálló jogi személyiséggel rendelkező, országos hatáskörű, önállóan működő és gazdálkodó, közel négyezer főt foglalkoztató központi költségvetési szerv, amely az államháztartásért felelős miniszter szakmai, törvényességi és költségvetési irányítása alatt áll.

A Kincstár felelős az állami költségvetés végrehajtása során a pénzforgalom lebonyolításáért és az elszámolásokért, a költségvetési pozíció előrejelzéséért és a likviditás menedzseléséért, továbbá meghatározott adatszolgáltatásokért. Nyilvántartja az állam által vállalt garanciákat és viszont garanciákat. Ellátja közel kilencszázezer közszférában foglalkoztatott illetményének számfejtését, az ehhez kapcsolódó adó- és járulék elszámolást és bevallást. Vezeti a költségvetési szervek törzskönyvi nyilvántartását - a cégnyilvántartáshoz hasonlóan - az alapító okiratok alapján. Nettó módon biztosítja a központi költségvetésből juttatott támogatásokat a helyi önkormányzatok, a többcélú kistérségi társulások és az egészségügyi intézmények részére, és ellenőrzi azok felhasználását. A helyi önkormányzatok, nemzetiségi önkormányzatok, társulások, térségi fejlesztési tanácsok és az általuk irányított költségvetési szervek körében kockázatelemzésen alapuló mintavétel alapján független szabályszerúségi pénzügyi ellenőrzést végez. Fogadja és összesíti a költségvetési beszámolókat. Folyósítja és 
ellenőrzi az EU-s és hazai támogatásokat, a jogosulatlanul kiutalt támogatásokat visszaköveteli. Ellátja a Terület- és Településfejlesztési Operatív Program közreműködő szervezeti feladatait. Számlát vezet a kincstári kör és a pénzforgalmi számlatulajdonosok részére, ellátja a kiadások teljesítéséhez, a bevételek beszedéséhez kapcsolódó pénzügyi feladatokat, valamint a kiadásokhoz kötődően likviditási és előirányzati fedezetvizsgálatot végez. A megyeszékhelyeken lévő állampénztári irodákban értékpapír forgalmazással és ahhoz kapcsolódó számlavezetéssel áll ügyfelei rendelkezésére.

A Magyar Államkincstárnak 19 megyei igazgatósága van, amelyek kirendeltségei intézik a nagy ügyfélforgalmat lebonyolító, decentralizált konkrét ügyeket. A Kincstár központja a költségvetési gazdálkodáshoz kapcsolódó ügyeket, valamint a költségvetési szervek finanszírozásával és beszámolásával kapcsolatos feladatokat látja el." (www.allamkincstar.gov.hu)

Ezekből a központi feladatokból végez a költségvetési szervek előirányzatgazdálkodásával, finanszírozásával, ellenőrzésével és adatszolgáltatásaival kapcsolatos munkafolyamatokat a Költségvetési Fejezetek Főosztálya.

Az államháztartás két alrendszerből áll, a központi alrendszerből és az önkormányzati alrendszerből. Mindkét alrendszer részt vállal az állami feladatok teljesítésében, melynek során az állam bevételekhez jut, illetve kiadásokat foganatosít. Éppen ezért célszerű az állam költségvetési politikájának értékelésekor ezeket összevontan és konszolidáltan kezelni. (BENCZES - KUTASI, 2010)

A Magyar Államkincstár végzi az alrendszerek törvényességi felügyeletét és finanszírozásuk lebonyolítását, illetve annak törvényességi és pénzügyi ellenőrzését. Továbbá a Kincstár feladatai közé tartozik még, hogy a központi költségvetés tervezetének előkészítésében, illetve a zárszámadás előkészítésében szorosan együtt működjön a Pénzügyminisztérium ezekért felelős főosztályaival. A Kincstár a feladatait beleértve a pénzügyi és törvényességi ellenőrzést is - a Pénzügyminisztérium rendeletei, utasításai alapján, valamint a felügyelete alatt végzi. A központi alrendszer tekintetében a központi költségvetés tervezésének és a zárszámadásnak az előkészítésében, a központi költségvetési szervek és a fejezeti kezelésű előirányzatok finanszírozásában, annak végrehajtásában és törvényességi és pénzügyi ellenőrzésében működik közre a Költségvetési Fejezetek Főosztálya.

A közfeladatok ellátásának finanszírozása külső és belső forrásból származik. (SIMON, 2012) Külső források közül a legjelentősebbek és tervezhetők az állami támogatások. Belső forrásnak tekinthetők többek között az állami vagyon hasznosítása útján szerzett bevételek, valamint a helyi adók is.

Magyarországon az állam éves költségvetésének tervezése az államháztartásért felelős miniszter irányítása alatt történik, miközben a Magyar Nemzeti Bank a monetáris politikájának eszközeivel, monetáris politikája veszélyeztetése nélkül támogatja a kormány gazdaságpolitikáját.

Az államháztartási mérleg bevételeinek és kiadásainak a halmozódását - ami az alrendszerek közötti pénzforgalomból adódik - ki kell szűrni, ezt a folyamatot nevezzük 
konszolidációnak. Erre szolgálnak a pénzforgalomban és az államháztartási számvitelben is együttesen alkalmazott Egységes Rovat Azonosítók (röviden: ERA kódok), amelyek alkalmasak a bevételek forrásonkénti és a kiadások jogcímenkénti besorolására, ezzel segítve a sikeres konszolidációt.

A költségvetési fejezetek címekre és alcímekre tagozódnak, melyek szervezeti és szabályozási szempontból összetartozó, tovább részletezett előirányzatok összességei. Az alcímek tovább-bontása az előirányzat-csoportok, amikben a közgazdasági tartalom szerint együvé tartozó bevételek és kiadások találhatóak meg működési és felhalmozási költségvetési bontásban. Az elóirányzat csoportokon belül pedig a kiemelt előirányzatok találhatóak, amik már célzottabban mutatják, mire mennyi kiadást terveztek.

A költségvetési szervek működéséhez szükséges anyagi forrás az állami támogatás és a saját bevétel. Az előirányzott kiadásokból kivonva a saját bevételeket adja a szükséges állami támogatás mértékét. Az állami támogatás előirányzata csak alaptevékenység végzésére használható fel.

A 2017. évi elemi költségvetés elkészítéséig a költségvetési szervek megszerkesztették a kincstári költségvetést, a Magyar Államkincstár által az egységes adatszolgáltatások számára múködtetett KGR-K11 rendszerben. Ami a költségvetési törvény keretszámait követve a kiemelt előirányzatokat foglalta magába. Az elemi költségvetés az egységes rovatrend szerinti részletezésben tartalmazta a közgazdasági osztályozás szerinti adatokat. A 2018. évtől már csak az elemi költségvetést kell elkészíteni a költségvetési szerveknek. A költségvetési szervek további adatszolgáltatásaikat is a KGR-K11 rendszerben nyújtják be a Kincstár felé. Ebben a rendszerben ellenőriz és készít kimutatásokat az államháztartás gazdálkodásáról a Magyar Államkincstár Költségvetési Fejezetek Főosztálya, ezen belül is a Költségvetési Információs Osztály.

A költségvetési politikán belül valósul meg a költségvetési rend, ami az államháztartási bevételek, kiadások és az egyenleg tudatos alakításának jól meghatározott, szabályozott rendszere.

Látható, hogy egy ország működéséhez szükséges költségvetés tervezése és annak végrehajtásának ellenőrzése mennyire fontos feladat egy állam számára, hiszen ezen keresztül valósítja meg állami funkcióit, ezen keresztül tud jól múködő államigazgatást létrehozni. Mindez csak ellenőrzött keretek között valósulhat meg, ún. kincstári rendszerben. A jelenlegi magyar államháztartási rendszerben a kincstári funkciókat két szervezet látja el. A költségvetési rend szerint gazdálkodók pénzellátása, az állami pénzek kezelése a Magyar Államkincstáron keresztül történik, az államadósság kezelés pedig az Államadósság Kezelő Központon keresztül valósul meg.

„A Magyar Államkincstár küldetése: a közpénzek kifizetése, és ezen kifizetések ellenőrzése. Feladata a közpénzek útjának nyomon követése, hogy jogosulatlan kifizetések ne történjenek.

Mindeközben a pénzügyi szolgáltatói tevékenysége során a kiadásokhoz kötődően likviditási és előirányzati fedezetvizsgálatot, valamint alaki, formai és pénzügyi ellenőrzést végez.” (BLUMNÉ - VÖRÖS, 2010) 
Továbbá közremúködik az európai uniós pénzeszközökkel kapcsolatosan jogszabályban, kormányhatározatban megszabott költségvetési, végrehajtási, ellenőrzési és pénzforgalmi feladatok ellátásában, és ellátja a jogszabályban meghatározott, európai uniós forrásból származó és egyéb nemzetközi támogatásokkal kapcsolatosan a támogatások fogadásáért felelős kifizető hatósági és igazoló hatósági feladatokat, valamint a Nemzeti Alap számára elöírt feladatokat.

\section{1. táblázat. A központi költségvetési szervek fejezeteinek besorolás}

\begin{tabular}{|c|c|}
\hline $\begin{array}{c}\text { Az Országgyülés irányítása alá tartozó } \\
\text { fejezetek }\end{array}$ & $\begin{array}{c}\text { A Kormány irányítása alá tartozó } \\
\text { fejezetek }\end{array}$ \\
\hline I. Országgyülés & X. Igazságügyi Minisztérium \\
\hline I. Egyenlő Bánásmód Hatóság & XI. Miniszterelnökség \\
\hline I. Magyar Energetikai és Közmű-szabályozási & XII. Agrárminisztérium \\
\hline Hivatal & XIII. Honvédelmi Minisztérium \\
\hline I. Nemzeti Választási Iroda & XIV. Belügyminisztérium \\
\hline I. Nemzeti Emlékezet Bizottságának Hivatala & XV. Pénzügyminisztérium \\
\hline Adatvédelmi & XVI. Nemzeti Adó- és Vámhivatal \\
\hline Információszabadság Hatóság & XVII. Innovációs és Technológiai \\
\hline I. Közbeszerzési Hatóság & Minisztérium \\
\hline $\begin{array}{l}\text { II. Köztársasági Elnökség } \\
\text { III. Alkotmánvbíróság }\end{array}$ & $\begin{array}{l}\text { Országos Atomenergia Hivatal: fejezeti } \\
\text { jogosultsáogal rendelkező kormányhivatal }\end{array}$ \\
\hline $\begin{array}{l}\text { IV. Alapvető Jogok Biztosának Hivatala } \\
\text { V. Állami Számvevőszék }\end{array}$ & $\begin{array}{l}\text { Szellemi Tulajdon Nemzeti Hivatala fejezeti } \\
\text { jogosultsággal rendelkező kormányhivatal }\end{array}$ \\
\hline VI. Bíróságok & XVIII. Külgazdasági és Külügyminisztérium \\
\hline VIII. Ügyészség & XIX. Uniós Fejlesztések \\
\hline XXX. Gazdasági Versenyhivatal & XX. Emberi Erőforrások Minisztériuma \\
\hline XXXIII. Magyar Tudományos Akadémia & XXI. Miniszterelnöki Kabinetiroda \\
\hline XXXIV. Magyar Művészeti Akadémia & XXII. Miniszterelnöki Kormányiroda \\
\hline $\begin{array}{l}\text { XXXV. Nemzeti Kutatási, Fejlesztési és } \\
\text { Innovációs Hivatal }\end{array}$ & XXXI. Központi Statisztikai Hivatal \\
\hline
\end{tabular}

Forrás: A kö̈pponti költségvetésröl szóló 2017. évi C. törvény szerint

\section{ANYAG ÉS MÓDSZER}

A Magyar Államkincstár szervezetén belül az Államháztartási Ügyekért Felelős Elnökhelyettes közvetlen irányítása alá tartozik a Költségvetési Fejezetek Főosztálya, továbbiakban röviden Főosztály.

A Főosztály a központi költségvetési szervek közül a költségvetési törvény szerkezete szerinti I-VIII., X.-XXXV. fejezetekhez tartozó központi költségvetési szervek, valamint a fejezeti kezelésű előirányzatok költségvetésének végrehajtásáról készített adatszolgáltatások ellenőrzését végzi.

A Főosztály négy osztályból áll, Humán Fejezetek Osztálya, Gazdasági és Igazgatási Fejezetek Osztálya, Védelmi és Rendészeti Fejezetek Osztálya, valamint a Költségvetési Információs Osztály.

A Humán, a Gazdasági és Igazgatási, illetve a Védelmi és Rendészeti Fejezetek Osztályai között vannak a költségvetési törvény I-VIII., X.-XXXV. fejezetei elosztva. A 
Költségvetési Információs Osztállyal közösen ellenőrzik és egyeztetik a kincstári rendszeres adatszolgáltatásokat és a kincstári költségvetési jelentéseket, közreműködnek a zárszámadás előkészítésében, adatot és információt gyűjtenek a költségvetési szervek és fejezeti kezelésű előirányzatok előirányzat és teljesítési adatairól készítendő számszaki és szöveges értékeléseihez. Részt vesznek a jogszabálytervezetek, előterjesztések, belső szabályozó eszközök, tájékoztatók előkészítésében, véleményezésében, előterjesztik a módosítási javaslataikat, továbbá adatokat szolgáltatnak a szakterületüket érintô megkeresésekre a közérdekű adatokra és a közérdekből nyilvános adatokra vonatkozó jogszabályi előírások alapján.

A Védelmi és Rendészeti Fejezetek Osztálya ezeken túl más szervezeti egységek munkájában közreműködve részt vesz a Kincstár és a kincstári rendszer továbbfejlesztésével kapcsolatos koncepciók kialakításában, és a jogi szabályozás előkészítésében, illetve meghatározza az informatikai rendszerek jogszabály-változás miatti, illetve új feladatokhoz kapcsolódó fejlesztési, módosítási igényét, valamint a szakmai követelményeket.

A Költségvetési Információs Osztály feladatai a Főosztály feladatkörébe tartozó valamennyi fejezetre vonatkozóan a többi osztállyal közösen végzett, feladatokon túl naprakészen nyilvántartani a havi és éves prognózis elkészítéséhez szükséges kiadási és bevételi teljesítéseket, az elemi költségvetéssel rendelkező intézmények tartozásállományát.

Az Információs osztály elkészíti a Magyar Államkincstár honlapján megjelenő adatszolgáltatásokhoz szükséges információkat és tájékoztatókat, folyamatosan figyelemmel kíséri és aktualizálja a szakterülethez tartozó információs anyagokat. Havonta összefoglaló értékelést készít a központi költségvetési szervek, fejezeti kezelésű előirányzatok előirányzati és teljesítési adatairól számszaki és szöveges formában.

A Főosztály látja el a KGR-K11 rendszerbe érkező adatszolgáltatások ellenőrzési, jóváhagyási feladatait a központi költségvetési szervek és a fejezeti kezelésű előirányzatok tekintetében, valamint ő ellenőrzi az államháztartás információs rendszerébe, a KGRK11 rendszerbe betöltendő kincstári nyilvántartások szerinti adatok megfelelőségét. Folyamatos kapcsolatot tart a fejezetekkel és intézményekkel a KGR-K11 rendszer megfelelő működése és az adatszolgáltatások teljesíthetősége érdekében, ehhez kapcsolódóan az általuk jelzett, a KGR-K11 rendszert érintő problémákat megvizsgálja és a szükséges módosítások végrehajtása érdekében továbbítja az Államháztartási Összefoglaló és Adatszolgáltató Főosztály részére. Ezzel kapcsolatban a fejezetek, intézmények részére tanácsadást biztosít a költségvetéshez, a beszámoláshoz és az időközi adatszolgáltatásokhoz kapcsolódóan felmerült számviteli kérdésekben, illetve figyelemmel kíséri a KGR-K11 rendszerben a központi költségvetési szervek, fejezetek adatszolgáltatási kötelezettségeinek teljesítését. Ehhez kapcsolódóan bírságot szabhat ki az Áht. (Áht. 2011. évi CXCV. tv 108.S (3) bek.) hatályos jogszabályainak megfelelően azon adatszolgáltatók részére, akik határidőre nem vagy nem megfelelő minőségben teljesítik adatszolgáltatási kötelezettségüket a KGR-K11 rendszerben. 
Ellenőrzi az egyezőséget a KGR-K11 rendszerben teljesített adatszolgáltatások és a főkönyvi kivonatok adatai között, szükség esetén felszólítja az adatszolgáltatókat a javításra, indoklások megadására.

A Főosztály végzi a Kincstár által végzett köztartozás-vizsgálat rendszerének jogszabályoknak megfelelő működtetését, koordinálását, nyilvántartásának vezetését, illetve az ezekkel kapcsolatos reklamációk kezelését. Mindezek szigorú működési rend szerint működnek, melyeket a Költségvetési Fejezetek Főosztály ügyrendje tartalmaz a vonatkozó jogszabályokkal, a Kincstár Elnöki utasításaival és a Múködési és Szervezeti Szabályzatával összhangban.

\section{EREDMÉNYEK}

Az államháztartás alrendszerei költségvetése végrehajtásának pénzügyi lebonyolítását és tartalmi, formai, törvényességi, számviteli és pénzügyi ellenőrzését a Magyar Államkincstár végzi. Az ellenőrzés lefolytatásához a központi költségvetési szervek az Áht. (2011. évi CXCV. tv. 107.』 (1) bek.) és az Ávr. (368/2011 (XII.31.) Korm. rendelet 167/M.S (1) bek. - 5. mell.) előírásainak megfelelően időről-időre kötelesek adatot szolgáltatni a Magyar Államkincstár felé, ezzel hatékonyan támogatva a közpénzek takarékos, átlátható és ellenőrzött felhasználását. (allamhaztartas.kormany.hu/a-hazaiallamhaztartasi-belso-kontroll-bemu) Ehhez a Kincstár az Áht. rendelkezésének megfelelő információs rendszert alakított ki, mely elemzésre és értékelésre is alkalmas módon segíti „államháztartási pénzügyi folyamatok tervezését, az előirányzatok kialakítását, a költségvetés végrehajtását és ellenőrzését." (2011. évi CXCV. tv. 102.』 (1) bek.) Ennek az információs rendszernek a része a KGR-K11 rendszer is, amelyen keresztül időszakos adatszolgáltatásokat teljesítenek a központi és az önkormányzati költségvetési szervek is a Kincstár felé. Ebben a rendszerben dolgozik a Költségvetési Fejezetek Főosztálya Költségvetési Információs Osztálya is.

\section{A kötelező adatszolgáltatások}

A költségvetési szervek az államháztartás számviteléről szóló 4/2013. (I.11) Korm. rendelet által szabályozott módon végzik a könyvelésüket, és készítik az ehhez kapcsolódóan vezetett részletező nyilvántartásokat.

Mind a központi, mind az önkormányzati költségvetési szervek kötelesek havonta időközi költségvetési jelentést készíteni kiadásaikról és bevételeikről az adott időszak végi adatokkal, amit az államháztartás végrehajtásáról szóló kormányrendeletben meghatározott határidőn belül megküldenek a Kincstár részére ellenőrzésre, jóváhagyásra. (Ávr. 368/2011 (XII.31,) 169.\$)

Negyedévente kötelesek időközi mérlegjelentést készíteni vagyoni helyzetükről az adott havi időközi költségvetési jelentéssel összhangban. Ezt az irányító szervi ellenőrzést, jóváhagyást követően az előírt határidőn belül a Kincstár is ellenőrzi, jóváhagyja a volt Nemzetgazdasági Minisztérium által kiadott Időközi adatszolgáltatások felülvizsgálatának módszertana segítségével. (Ávr. 368/2011 (XII.31,) 170.』) 
Az államháztartási törvény 108/A \-a értelmében az államháztartás központi alrendszerébe tartozó költségvetési szerv havi rendszerességgel adatszolgáltatást köteles teljesíteni a költségvetési évben várhatóan felmerülő kiadásairól és bevételeiről, valamint kötelezettségvállalásairól, más fizetési kötelezettségeiről és követeléseiről. (Ávr. 368/2011 (XII.31,) 172/A.S)

Az adatszolgáltatások közül az időközi költségvetési jelentéseket, az időközi mérlegjelentéseket, az éves költségvetési beszámolókat (megszűnő, átalakuló költségvetési szerv esetében is) és az elemi költségvetéseket az adatszolgáltató költségvetési szervek a Kincstár erre a célra kialakított információs rendszerében, a KGRK11 rendszerben szolgáltatják. Ebbe a rendszerbe töltik fel a megszabott határidőkig az adatszolgáltatásokat és az őket alátámasztó főkönyvi kivonatokat. Ebből a rendszerből végzik a központi költségvetési szervekre vonatkozó ellenőrzést a Költségvetési Információs Osztály költségvetési referensei.

A költségvetési referensek a Pénzügyminisztérium által ellenőrzési célra kiadott Időközi adatszolgáltatások felülvizsgálati módszertana, valamint az Ellenőrzési szempontok az éves költségvetési beszámoló felülvizsgálatához című dokumentumok előírásai alapján végzik az adatszolgáltatások ellenőrzését.

\section{Az időközi költségvetési jelentés ellenőrzése}

Az időközi költségvetési jelentés készitését az államháztartásról szóló törvény (Áht. 2011. évi CXCV. tv. 108.』 (1) bek.) és az államháztartás végrehajtásáról szóló kormányrendelet (Ávr. 368/2011 (XII.31,) 169.S (1) és (2) bek.), illetve annak 5. számú mellékletének 21. pontja írja elő. (2018. évi időközi költségvetési jelentés kitöltési útmutatója a központi alrendszer számára) E rendelet alapján ez a jelentés a kincstári költségvetési jelentésen alapul, melyet a Kincstár havonta, a tárgyhónapot követő hónap 10. napjáig készít el a tárgyhónap végi előirányzati és teljesítmény adatok ismeretében, az egységes rovatrend szerinti bontásban. A központi költségvetési szervek, illetve a fejezeti kezelésű előirányzatok Kincstár által nyilvántartott előirányzati és teljesítési adatai alapján készülő kincstári költségvetési jelentés a Magyar Államkincstár honlapján a Kincstári rendszeres adatszolgáltatások menü alatt havi rendszerességgel közzétételre kerül. A kincstári adatok az adatszolgáltatók által már nem módosíthatóan megjelennek az időközi költségvetési jelentésben. Az adatszolgáltatóknak a saját - főkönyvi kivonatukkal egyező - előirányzati, teljesítési és kötelezettségvállalási adataikkal kell feltölteniük az adatszolgáltatást. Természetesen minden intézmény csak a saját adatszolgáltatásait, adatait láthatja, a fejezetek pedig csak az irányításuk alá tartozó szervekét. Ezekkel az adatokkal az adatszolgáltatók főkönyvi kivonatában szereplő értékeknek meg kell egyezniük, egyéb esetben a szervezetnek a Kincstárral egyeztetnie kell. Az esetleges eltérések feltüntetésre kerülnek a KGR-K11 rendszerbeli adatbázisban is, hogy a későbbiek folyamán az eltérésekből adódó szükséges módosításokat meg tudják tenni az adatszolgáltató könyvelésében, vagy a Kincstári nyilvántartásban az e-adaton keresztül megküldött erre szolgáló fejezeti vagy intézményi hatáskörben benyújtott előirányzatmódosítási 
bizonylatokon, illetve az átutalási megbízásokhoz tartozó vagy önállóan benyújtható kiegészítő szelvényen.

Az időközi költségvetési jelentés KGR-K11 rendszerbeli adatszolgáltatása négy űrlapból áll, melyek az adatokat forintban tartalmazzák, mint ahogy a főkönyvi kivonatban is. A sikeres és egyértelmű azonosítás érdekében az adatszolgáltatásokat végző szervezetek adatai az űrlapok fejléceiben megtalálhatóak. A jó áttekinthetőség érdekében külön űrlapon jelennek meg a költségvetési és a finanszírozási kiadások, illetve a költségvetési és finanszírozási bevételek. Ez azért is célszerű, mert más-más szabályok érvényesek a kiadási és a bevételi, illetve a költségvetési és a finanszírozási ûrlapok adataira.

A költségvetési jelentések adatbázisait a KGR-K11 rendszerben minden hónap 10-ig megnyitja az adatszolgáltatások informatikai hátterének biztosításáért felelős Államháztartási Összefoglaló és Adatszolgáltatási Főosztály Államháztartási Információs és Szabályozási Osztálya, azaz elérhetővé teszi a költségvetési szervek és az ellenőrző szervek részére. Minden költségvetési szerv csak a hozzá tartozó adatszolgáltatásokat látja és töltheti, illetve az irányító, felügyeleti szervek is csak a felügyeletük alá tartozó szervek adatszolgáltatásait láthatják, ellenőrizhetik és hagyhatják jóvá. Ezen tevékenységek teljesítésének határidejérôl az államháztartás végrehajtásáról szóló kormányrendelet rendelkezik. (Ávr. 368/2011 (XII.31,) 169.S (2) bek.)

A volt Nemzetgazdasági Minisztérium Ellenőrzési szempontjaiban rögzített előírás az, hogy évente egyszer legyen ellenőrizve minden központi költségvetési szerv legalább egy adatszolgáltatása. Amennyiben egy adatszolgáltatás nem a jogszabályoknak megfelelő, akkor az azt készítő költségvetési szerv következő három adatszolgáltatását is ellenőrizni szükséges. Ha ezek közül az ellenőrzött adatszolgáltatások közül bármelyik nem felelne meg az előírásoknak, addig kell végezni az adott szerv adatszolgáltatásainak az ellenőrzését, amíg három egymást követő adatszolgáltatása nem lesz hibátlan. Ezért érdemes megtervezni, melyik szerv melyik adatszolgáltatását ellenőrizzük, hogy a költségvetési év során valamennyi szerv legalább egy adatszolgáltatása ellenőrzés alá kerüljön.

Formai követelmények ellenőrzésének döntő többségét mára már beépítették a KGRK11 rendszer szabálybázisába, de szúrópróbaszerūen manuálisan is ellenőrzik ezen követelmények meglétét. A rendszerbe épített ellenőrzési szabályok megakadályozzák, hogy a költségvetési szervek formailag hibás vagy hiányos adatszolgáltatást nyújtsanak be. Az államháztartás számviteléről szóló kormányrendelet előírásainak megfelelően ellenőrizni szükséges az eszközök és források előirányzati és teljesítési összegének egyezőségét. Azaz a költségvetési kiadások és egyes költségvetési szerveknél előforduló finanszírozási kiadások összege nem lépheti túl a költségvetési bevételekből és a finanszírozási bevételekből származó bevételek összegét. A költségvetés elkészítésekor törekedni kell arra, hogy a költségvetési mérleg ne legyen deficites.

Továbbá a költségvetési és finanszírozási kiadási űrlapokon soronként (ERA kódonként, rovatonként) ellenőrizni kell az adatszolgáltatást mind a sorokon belül, mind főkönyvi egyezőség szempontjából. Tehát rovatonként a módosított kiadási előirányzatok tervezett 
összegét nem haladhatják meg a tárgyévi vállalt (esedékes és végleges) kötelezettségek. (Áhsz. 4/2013 (I.11,) Korm. rendelet 17. mell. 1. pont)

A költségvetési számvitelben négyféle kötelezettségvállalás létezik:

- a „tárgyévi esedékes kötelez̧ettségvállalások”, amik szolgáltatási szerződések aláírásakor keletkeznek a könyvelésben, illetve személyi juttatások és munkaadókat terhelő járulékok könyvelésekor a szervezet munkavállalói létszáma alapján képződik

- a „tárgyévi végleges kötelezettségvállalások” a számlák beérkezésekor, illetve a személyi juttatások kifizetésekor keletkeznek.

- a „tárgyévet követöen esedékes kötelezettségvállalást” jogszabályi előírások alaján egyes rovatokon kötelező, míg más esetekben adott a választási lehetôség az előirányzatmódosításra. Meg nem szűnő költségvetési szervek esetében például kötelező háromévre előre kötelezettséget vállalni a törvény szerinti illetmények, a munkaadókat terhelő járulékok, valamint a dologi kiadások bizonyos sorain, valamint az ellátottak pénzbeli juttatásai rovatokon, melyeket az államháztartásról szóló törvény ír elő számukra és a nagyságát is szabályozza. (Áht. 2011. évi CXCV. tv. 36. (4) bekezdés)

- A „tárgyévet követó évre végleges kötelezettségvállalás” csak év végén, korábban egyes sorokban csak indokolt esetben lehetséges.

Amennyiben ezek az egyezőségek fennállnak, úgy a további főkönyvi számlákkal történő egyeztetés is lefuttatható.

Ha a fenti ellenőrzések lefuttatásakor a KGR-K11 rendszer nem jelez eltérést az adatszolgáltatásban, úgy az feladható a rendszerben irányítószervi és Kincstári ellenőrzésre.

Tartalmi ellenőrzések során a kötelező adatok meglétének ellenőrzésén kívül a többi esetben a költségvetési szerveknek indokolnia szükséges a nem tipikus adatok meglétét, illetve a szükséges adatok hiányát.

A költségvetési kiadások űrlapján a törvény szerinti illetmények rovatnak, illetve a munkaadókat terhelő járulékok rovatnak kötelező adatot tartalmazniuk amennyiben az elemi költségvetés meghatározott űrlapjának az erre kijelölt soraiban létszám került kimutatásra, hiszen ekkor nem megszűnő intézményről van szó.

Az általános forgalmi adó esetében is meg kell vizsgálni, hogy az ÁFA köteles kötelezettségvállalásokhoz, kifizetésekhez el van-e számolva forgalmi adó. Ennek az esetleges hiánynak az okait szintén fel kell tüntetni az adatszolgáltatás indokai között, mint minden más indoklásköteles esetben. Az általános forgalmi adó elszámolásának elmaradása csak fordított ÁFA esetén fogadható el, vagy abban az esetben, ha a kiadás adómentes tevékenységgel kapcsolatos.

Az államháztartáson belüli megelőlegezések visszafizetését, és a központi irányítószervi támogatások folyósítását, mint finanszírozási kiadásokat egyeztetnünk szükséges a Kincstári nyilvántartásokkal. A megelőlegezések visszafizetésének előirányzati és 
teljesítési adatainak az előző év mérlege tárgyév végi állományában szereplő adattal egyezniük kell.

Ezzel párhuzamosan az előirányzati és a teljesítés adatok a Kincstári nyilvántartásban is szerepelnek. A kincstári adatok szintén szerepelnek az időközi költségvetési jelentés adatszolgáltatásokban a könyvelési adatok mellett. Az egyezőséget év közben nem lehet garantálni, mert a Kincstári adatok havonta egyszer, havi összesítésként kerülnek rögzítésre egy adattáblában, amiből az adatok a tárgyhónapot követő havi adatszolgáltatás megnyitásakor feltöltésre kerülnek a megfelelő űrlapok megfelelő soraiba. Az adatszolgáltatók minden hónapban látják, hogy előirányzati, illetve teljesítési adataik mennyiben térnek el a Kincstár által nyilvántartott adatoktól. Így folyamatosan lehetőségük van korrigálni a későbbi egyezőségek biztosítása érdekében. A fő cél az, hogy év végére ezek az adatok megegyezzenek, azaz a valós főkönyvi adatok egyezzenek a Kincstári nyilvántartásban szereplő adatokkal. Az eltérések kiküszöbölése érdekében a költségvetési szerveknek rendelkezésükre áll minden év első hónapja - korrekciós időszak - arra, hogy a megfelelő bizonylatok Kincstár felé történő benyújtásával megteremtsék a kincstári és a főkönyvi nyilvántartás közötti egyezőséget. A korrekciós időszakról készült információs táblákat a Kincstár a honlapján megjeleníti.

Amennyiben az adatszolgáltató által megadott indoklások nem elfogadhatók, akkor vagy pedig az adatszolgáltatást és ezzel párhuzamosan a főkönyvet, vagy a megadott indoklást kell javítani. Adatszolgáltatás és főkönyv egyidejű javítása érdekében a már feladott adatszolgáltatás a fejezet által, illetve kincstári felülvizsgálat esetén a Kincstár által visszanyitható. Ha az adatszolgáltató elvégezte a kért módosításokat, az adatszolgáltatás a feladást követően pénzügyileg jóváhagyható.

A pénzügyileg jóváhagyott, lezárt adatszolgáltatások adatai átadásra kerülnek a Pénzügyminisztérium részére, ahol azok további feldolgozásra, összesítésre kerülnek.

\section{Az idöközi mérlegjelentés ellenốrzése}

Az időközi mérlegjelentés KGR-K11 rendszerbeli adatszolgáltatása a központi költségvetési szervek számára négy űrlapot tartalmaz. A mérleg űrlapján túl a részesedések és az utánuk járó osztalék, illetve a mérlegfolytonosság bemutatására szolgáló űrlapokat foglalja magába. A negyedik űrlapon, ami tájékoztató adatokat tartalmaz, a lejárt kötelezettségeket és követeléseket lehet bemutatni.

A részesedésekről szóló űrlapot csak azoknak a szerveknek kell kitölteniük, amelyek birtokolnak részesedést gazdasági társaságban. A mérlegfolytonosságot bemutatni azoknak az intézményeknek kell, amelyekbe egy megszűnő intézmény beolvad, vagy azoknak a vagyonátvevő szervezeteknek, amelyek átveszik egy jogutód nélkül megszűnő szerv vagyonát.

A mérlegjelentések adatbázisait a KGR-K11 rendszerben minden negyedévet követő hónap 10-ig megnyitja az adatszolgáltatások informatikai hátterének biztosításáért felelős Államháztartási Összefoglaló és Adatszolgáltatási Főosztály Adatszolgáltatási és Informatikai Osztálya, azaz elérhetővé teszi a költségvetési szervek és az ellenőrző 
szervek számára. Év végén azonban az utolsó negyedéves mérlegjelentésnek kettő adatbázisa van. A gyorsjelentésnek nevezett adatbázis az utolsó negyedéves adatok aktuális könyvelési adatait tartalmazza. A másik viszont az éves költségvetési beszámoló mérlegével megegyező, már korrigált, végleges év végi adatokat tartalmazza. Ahogy a költségvetési jelentéseknél, itt is minden költségvetési szerv csak a hozzá tartozó adatszolgáltatásokat látja és töltheti, illetve az irányító, felügyeleti szervek is csak a felügyeletük alá tartozó szervek adatszolgáltatásait láthatják, ellenőrizhetik és hagyhatják jóvá. Ezen tevékenységek teljesítésének határidejéről az államháztartás végrehajtásáról szóló kormányrendelet rendelkezik. (Ávr. 368/2011 (XII.31.) 170.』 (2) bekezdés)

A főkönyvi kivonattal való egyezőséget, az űrlapok összefüggő adatainak egyezőségét, valamint a számviteli egyezőségeket a KGR-K11 rendszer ellenőrzi a beépített szabálybázisok segítségével, így a kincstári ellenőrzést végző munkatársak csak szúrópróbaszerűen vizsgálják ezeket az összefüggéseket. Itt olyan adatokat kell vizsgálni az eszközök és források alakulása táblában, hogy az eszközök, illetve követelések tárgyidőszak végi adataiban feltüntetett értékei az elszámolt értékcsökkenések, értékvesztések összegével csökkentett, illetve növelt értékben legyenek kimutatva.

A mérlegfolytonosságot igazoló adatokat tartalmazó 1/C táblában fokozottan ellenőrizni kell, hogy az abban szereplő összegek egyeznek-e a megszűnő, beolvadó szervezet záró beszámolójában feltüntetett adatokkal.

A tájékoztató adatokat tartalmazó 1/D űrlapon csak a lejáró kötelezettségeket nincs lehetôségünk ellenőrizni, aminek egyeznie kell a Kincstár - AT01.Tartozásállomány nyilvántartásában a szervre vonatkozó, aktuálisan fennálló tartozás adatával. Mivel ez is havonta egyszer, minden hó végén kerül egy adattáblába, ezen adatok között is lehet eltérés, amiről egyeztetünk az adatszolgáltatóval, illetve a következő hónapban figyelemmel kísérjük a változásokat.

A főkönyvi kivonattal való egyezőség, illetve a számviteli egyezőségek megléte kerülhet sor az eszközök és források tábláinak tartalmi ellenőrzése a kincstári ellenőrzést végző munkatársak által.

Az immateriális javak, a tárgyi eszközök, a koncesszióba adott eszközök és a befektetett pénzügyi eszközök, illetve a beszerzett készletek után értékcsökkenést kötelező elszámolni, amennyiben van nyitó állományuk, vagy forgalom keletkezett azokon a főkönyvi számlákon, amelyeken ezek állományváltozása szerepel, azaz például új beruházás történt, vagy értéknövelő felújítások történtek, illetve amelyik szervezetnél lehetséges, forgatási vagy befektetési célú értékpapírok vásárlására került sor. Ezeket a változásokat a pénzforgalommal nem járó tranzakciók között kötelező kimutatni az űrlapon erre a célra kialakított oszlopban, kivéve, ha a csökkenések és a növekedések összege kiegyenlíti egymást.

Itt is figyelni kell arra, hogy részesedéseket és értékpapírokat bemutató rovatokon, könyviteli számlákon egyenleg csak azoknál a szervezeteknél fordulhat elő, amelyek számára ezt törvény biztosítja. Ekkor kell kitölteniük az 1/A űrlappal összhangban a részesedések bemutatására szolgáló 1/B űrlapot. 
A kincstárban vezetett forintszámlák egyenlegét egyeztetni kell a Kincstári számlavezető rendszer adataival.

December havi munkabér elszámolásának csak év végén lehet állománya.

Az azonosítás alatt álló tételeknél meg kell vizsgálni, hogy a tételek azonosítása folyamatos-e, azaz a tartozik forgalom mellett követel forgalom is szerepel a főkönyvi számláján.

A „nemzeti vagyon induláskori értéke és egyéb eszközök induláskori értéke és annak változásai” soron a záró állomány csak akkor térhet el a nyitó állománytól, amennyiben a szervezetet átalakulás, beolvadás érintette.

Meg kell bizonyosodni arról, hogy az előző évi megelőlegezés a január havi nettósítás során a követelésekkel szemben kivezetésre került.

Továbbá arról is meg kell bizonyosodni, hogy a költségek és a ráfordítások passzív időbeli elhatárolásaiból kivezetésre került az előzô évi december havi munkabér.

Amennyiben az adatszolgáltató által megadott indoklások nem elfogadhatók, akkor vagy az adatszolgáltatást és ezzel párhuzamosan a főkönyvet, vagy a megadott indoklást kell javíttatni. Az adatszolgáltatás és főkönyv egyidejü javítása érdekében a már feladott és jóváhagyott adatszolgáltatás a fejezet részéről, amennyiben kincstári felülvizsgálat által derül ki az eltérés, úgy a Kincstár részéről visszanyitható. Ha az adatszolgáltató elvégezte a kért módosításokat, az adatszolgáltatás a feladás, illetve a fejezet általi jóváhagyás után pénzügyileg jóváhagyható.

A pénzügyileg jóváhagyott, lezárt adatszolgáltatások adatai átadásra kerülnek a Pénzügyminisztérium részére, ahol azok további feldolgozásra, összesítésre kerülnek.

\section{Az éves költségvetési beszámoló ellenörzése}

Az éves költségvetési beszámoló adatszolgáltatása a tárgyév december havi időközi költségvetési jelentés 4 pénzforgalmi űrlapján túl a beszámolóhoz kapcsolódó alábbi űrlapokat is tartalmazza:

- Az 5. és a 6. űrlapok kormányzati funkciónként tartalmazzák a teljesített kiadásokat, illetve bevételeket,

- A 7. űrlap a maradványkimutatást,

- A 8. űrlapon a munkáltatók adatot szolgáltatnak a náluk foglalkoztatottak, és az esetlegesen általuk választott képviselők összetételéről, illetve a nekik folyósított személyi juttatásokról (fejezeti kezelésű előirányzatok esetében nem töltendő, mivel azt a fejezet biztosítja az előirányzat célját megvalósító munkaerőt, akihez az előirányzat a költségvetési törvény által sorolva lett),

- A 9. űrlapon mutatják be a foglalkoztatottak funkciócsoportonkénti megoszlását (fejezeti kezelésű előirányzatok esetében nem töltendő),

- A 10. és 11. űrlapokat nem töltik ki a központi költségvetési szervek, csak a társadalombiztosítás pénzügyi alapjai, illetve az önkormányzatok,

- A 12. űrlapon a mérleg kerül bemutatásra, 
- A 13. űrlapra az eredménykimutatás levezetése kerül,

- 14. űrlap volt korábban a szakfeladatonkénti költségek kimutatása a központi költségvetési szervek, az önkormányzatok és a fejezeti kezelésű előirányzatok részére, de funkciója megszűnt, használata nem kötelező,

- A 15. és 16. űrlap szolgál a tárgyi eszközök, immateriális javak, koncesszióba, vagyonkezelésbe átadott eszközök, továbbá az eszközök után elszámolt értekcsökkenés kimutatására,

- A 17. űrlap tájékoztató adatokat tartalmaz, melyeknek összhangban kell lennie a központosított illetményszámfejtés adataival.

Az 1-4. űrlapoknak egyezniük kell a tárgyév december hónapjában kimutatott halmozott adatokkal, amit az Áhsz. 39.S (1a) bekezdése ír elő. (Áhsz. 4/2013 (I.11,) Korm. rendelet 39. (1a) bek.) Ezért ezekben az ûrlapokban az adatok a már elfogadott december havi időközi költségvetési jelentés főkönyvi adataiból töltődnek be az Ávr. 169.』 (2) bekezdése szerinti határidőt követően. (Ávr. 368/2011 (XII.31,) 169.S (2) bek.) Ezután a főkönyvi előirányzatok és a teljesítések adatainak módosítása csak Pénzügyminisztériumi engedéllyel lehetséges. Ehhez kérelmet a Kincstárhoz - a KGR-K11 rendszer felületén a négy űrlappal egyező szerkezetű táblázatokon lehet benyújtani indoklással ellátva, amiben már az adatszolgáltató szerinti megfelelő adatok szerepelnek.

Különös figyelmet kell fordítani azokra a javítási kérelmekre, amelyek olyan teljesítés adatokban történő javítást tartalmaznak, amik államháztartáson belüli támogatásokat érintenek. Ekkor a partner adatszolgáltatását is ellenőrizni kell, hogy ott jó helyen szerepel-e az érintett támogatási összeg mert, ha nem, akkor ott is javítás szükségeltetik. Az olyan hibák javítására, amelyek később, a beszámoló elfogadását követően kerülnek feltárásra Állami Számvevőszék általi, vagy akár önellenőrzés során, az Áhsz. 54.』 előírása szerint (Áhsz. 4/2013 (I.11,) Korm. rendelet 39.』 (1a) bek.) csak a feltárás időszakának könyvelése keretében javíthatók.

Az 5. és a 6. ûrlapok kitöltéséhez a Pénzügyminisztérium által a központi költségvetési szervek, illetve fejezeti kezelésű előirányzatok részére engedélyezett kormányzati funkciók használhatók. Ennek ellenőrzését be lehetne állítani a KGR-K11 rendszer szabálybázisában, bár a folyamatos változások és a kormányrendeletek, kormányhatározatok, illetve a miniszteri rendeletek által engedélyezett kivételek kezelése miatt érdemesebb meghagyni a manuális ellenőrzést ebben a funkcióban.

A 8. és a 9. űrlapok ellenőrzését a központi költségvetési szerveket irányító és felügyelő fejezet végzi.

A 12. ûrlapon szereplő mérleg adatait a negyedik negyedéves időközi mérlegjelentés adataival veti össze a KGR-K11 rendszerbe épített ellenőrzés az egyezőség biztosítása érdekében. Az időközi mérlegjelentésnél alkalmazott, korábban már említett vizsgálatokon felül ellenőrizni szükséges, hogy az ûrlap 4., Módosítás oszlopa csak abban az esetben tartalmazhat adatot, ha az ellenőrzés az előző éves költségvetési beszámoló(k)ban elkövetett jelentős összegű hibá(ka)t állapított meg. Ekkor a 
módosításokat a mérleg minden tételénél az előző évi adatok mellett be kell mutatni . ( Áhsz. 4/2013 (I.11,) Korm. rendelet 9.』 (2) bek.) Továbbá ekkor kell azt is ellenőrizni, hogy amennyiben a 245. Nemzetközi támogatási programok pénzeszközei soron összeg van feltüntetve, azon nem szerepelhet kisebb összeg, mint ami az 57. Pénzeszközök sor azonos oszlopaiban szerepel.

Ide tartozik az Áhsz. 48.』 (7) bekezdésének azon előírása, hogy a 36. számlaosztályban nyilvántartott sajátos elszámolásokat, köztük az azonosítás alatt álló tételeket is a tárgyévet követő év január 31-ig, azaz a korrekciós időszak végéig rendezni szükséges. (Áhsz. 4/2013 (I.11,) Korm. rendelet 48.§ (7) bek.)

Az űrlapok közötti további összefüggések ellenőrzése mára már a KGR-K11 rendszerbe épített vizsgálat során történik.

A pénzügyileg jóváhagyott, lezárt adatszolgáltatások adatai átadásra kerülnek a Pénzügyminisztérium részére, ahol azok további feldolgozásra, összesítésre kerülnek.

\section{Elemi költségvetés ellenőrzése}

A központi költségvetési szerveknek az elemi költségvetésük elkészítésekor a beszámoló űrlapjai közül az 1-4. és a 8-9. ûrlapokat kell kitölteniük az aktuális költségvetési törvény alapján. Ennek vizsgálata már a KGR-K11 rendszer szabálybázisába beépített ellenőrzésként történik, ami annyit jelent, hogy addig nem is tudják a szervezetek az adatszolgáltatásokat feladni, amíg a tárgyévet követő évre vonatkozó költségvetési törvénnyel való egyezőség nem áll fenn. Ezt a szervezetek irányító fejezetei jóváhagyják, így már pénzügyileg jóváhagyható és lezárható az elemi költségvetés.

\section{Bírságolás}

Az államháztartásban a bírságolás jogalapját az államháztartási törvény 108.』 (2011. évi CXCV. tv. 108.S (3) bek.) teremti meg. Ennek rendelete szerint amennyiben az adatszolgáltatás kötelezettje kötelezettségét a neki felróható okból nem vagy késedelmesen teljesíti, illetve ha az adatszolgáltatás tárgyával kapcsolatos lényegesnek minősülő információt nem vagy tévesen közöl adatszolgáltatásában, akkor az Ávr.-ben (Ávr. 368/2011 (XII.31.) Korm. rendelet 171.』 (1) bek.) meghatározott mértékű bírságot fizet. Az adatszolgáltatások benyújtásának határidejét az időközi költségvetési jelentések és az időközi mérlegjelentések esetében az Ávr. (Ávr. 368/2011 (XII.31.) Korm. rendelet 169.S (2) és 170.』 (2) bek.) szabja meg, a költségvetési beszámoló esetében az Áhsz. (Áhsz. 4/2013 (I.11.) 32.§ (1) bek.) A bírságot az Államkincstár Költségvetési Fejezetek Főosztálya Költségvetési Információs Osztály határozatban szabja ki, amit az elnöke, vagy az államháztartásért felelős elnökhelyettes ír alá, ezért fellebbezésnek helye nincs. (2016. évi CL. tv. az általános közigazgatási rendtartásról 116.\$ (1) bek. és (4) bek. a) pont) A bírság mérséklése vagy részletekben történő megfizetésére benyújtott kérelmek esetében a meghozott mérséklést szintén határozatban hozzák meg az Költségvetési Információs Osztály költségvetési referensei. Valamint jogalap nélküli vagy későn benyújtott kérelmek esetében ők is utasítják el a kérelmet végzésben. 
A kiszabott határozat ellen, továbbá abban az esetben, ha az adatszolgáltató nem ért egyet a kérelmet elbíráló határozatban vagy végzésben foglaltakkal, akkor a határozat ellen az adatszolgáltató az illetékes Közigazgatási és Munkaügyi Bírósághoz keresetet nyújthat be az általános közigazgatási rendtartásról szóló törvény (2016. évi CL. tv. 114.S (1) bek.), illetve az államháztartásról szóló törvény (2011. évi CXCV. tv. 108.S (5) bek.) rendelkezéseiben foglaltak szerint a Főosztályon keresztül. A keresetet a Jogi és Törzskönyvi Főosztály állásfoglalásával együtt megküldi az illetékes bíróságnak.

\section{Határozatok száma}

(2015. I. negyedév - 2018. III. negyedév)

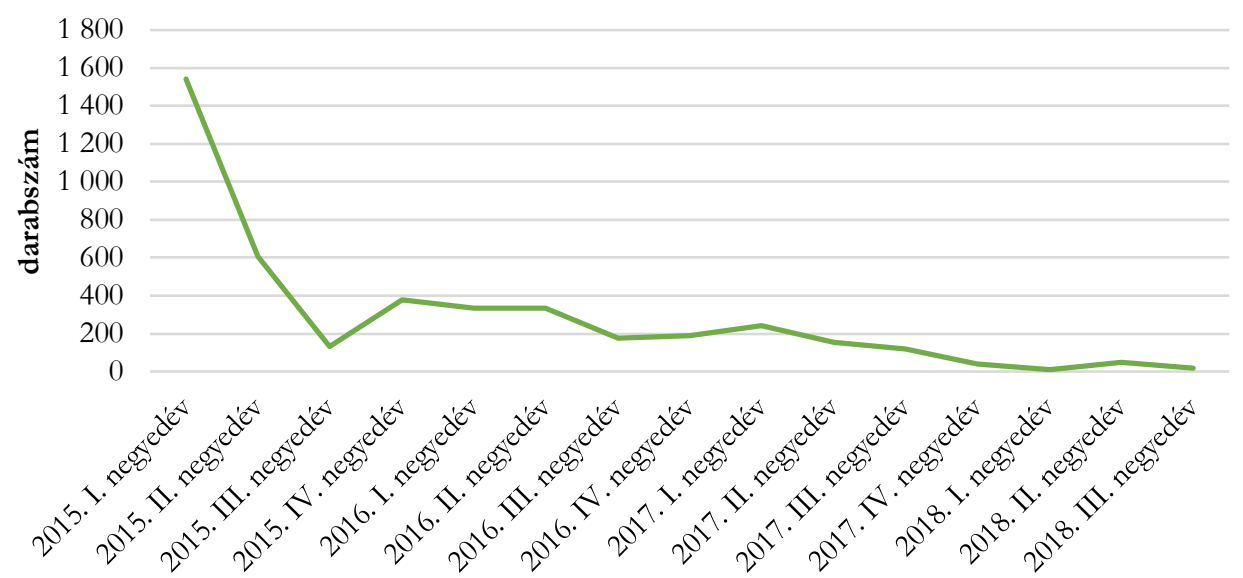

1. ábra. Az adatszolgáltatási fegyelem javulása a KGR-K11 rendszer bevezetése óta Forrás: saját szerkesztés Kincstári belsö adatok alapján

Amint azt a 1. ábra is jól szemlélteti, a KGR-K11 rendszer 2014 év végi bevezetése és az adatszolgáltatások határidőn túli vagy nem teljesítése esetén bírság kiszabása nagy lépés volt az adatszolgáltatási fegyelem javulásában. A szabályok betartása, betartatása egyszerűbb és hatékonyabb lett, a határidők és az előírásoknak megfelelő adatszolgáltatás minősége pedig rohamosan javult a rendszer működésének utóbbi négy éve alatt. Ez azt eredményezte, hogy a rendszerbe épített egyeztetési szabályoknak köszönhetően egy adatszolgáltatás ellenőrzésére fordítandó idő is jóval rövidebb lett, ezért hamarabb fény derül a hibákra és kerülhet sor a javításukra. Ezzel párhuzamosan a kiszabott és ténylegesen befizetett bírságok nagysága is szépen lecsökkent. 


\section{Folyamatok}

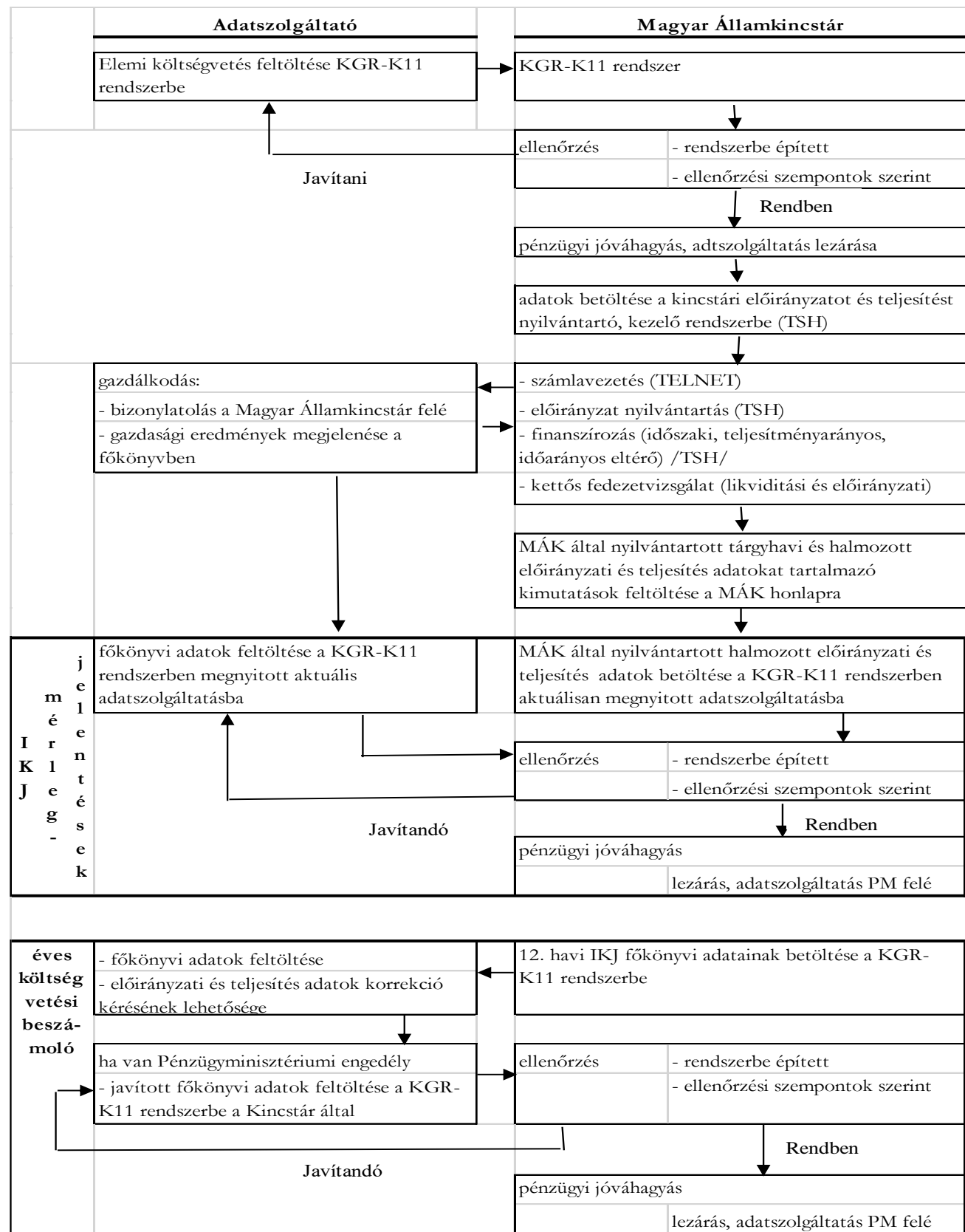

2. ábra. A Költségvetési Fejezetek Főosztálya munkafolyamatai

Forrás: saját szerkesżtés 
A 2. ábra jól szemlélteti azt, hogyan áll össze a központi költségvetési szervek finanszírozása, adataik nyilvántartása és adatszolgáltatásaik ellenőrzése a Költségvetési Fejezetek Főosztálya munkafolyamataiban az aktuális jogszabályoknak megfelelően.

Az alapot minden évben a tárgyévi költségvetési törvény adja, a folyamat innen indul és a zárszámadási törvény elfogadásával ér véget. Ez a folyamat a tárgyévet követő évi költségvetési törvény megalkotásával indul újra, bár a jogszabályok által kiszabott határidők miatt a tárgyévet megelőző év zárszámadási és a tárgyévet követő évi költségvetési törvény előkészítése párhuzamosan folyik.

Jól megfigyelhető, hogy a szervek előirányzat-módosítása és a finanszírozása mennyire szorosan összefüggő, oda-vissza működő folyamat a gazdálkodó szervezetek és a Kincstár között. A kettős fedezetvizsgálat során mind a rendelkezésre álló előirányzatot, mind a likvid fedezet rendelkezésre állását vizsgálni szükséges az utalások teljesülése előtt. Ezek benyújtásának lehetőségét és engedélyezését az Áht. és az Ávr. szabályozza. Az engedélyezett és végrehajtott előirányzat-módosításokat és a finanszírozás teljesítését a MÁK nyilvántartja, ezekből készítik el havonta azokat a táblákat, amiket a MÁK honlapján is közzé tesznek, és ezekből a táblákból olvasódnak be a Kincstári adatok az adatszolgáltatásokba azok publikálásakor. Ezután az Ávr. által meghatározott határidőn belül az adatszolgáltatók feltöltik a főkönyvi adataikat az adatszolgáltatásokba a Kincstári adatokkal párhuzamosan, illetve a főkönyvi kivonatukat, és az adatszolgáltatásuk KGRK11 rendszerbeli feladásával jelzik annak elkészültét. Ezt ellenőrzi, valamint a szükséges javítások elvégzése után azt jóváhagyja, szükség szerint a központi költségvetési szerv gazdálkodását, működését felügyelő, irányító fejezet, illetve a Magyar Államkincstár Költségvetési Fejezetek Fôosztálya Költségvetési Információs Osztálya.

Ezután információt szolgáltatnak az elvégzett feladatokkal és az adatszolgáltatásokkal kapcsolatosan a Pénzügyminisztérium részére. Amennyiben az éves költségvetési beszámoló adatszolgáltatásának lezárására került sor, akkor a megküldött adatok birtokában a Pénzügyminisztérium felelős főosztálya összeállítja a zárszámadáshoz felhasználandó adatokat. Ezzel párhuzamosan az államháztartásért felelős miniszter irányításával már készülhet a tárgyévet követő évi költségvetési törvény, amelynek elfogadásával és kihirdetésével újra indul a folyamat.

Az időközben bevezetett ERA kódokkal összehangolt, valamint az egymáshoz hasonló szerkezetű adatszolgáltatásokat tartalmazó KGR-K11 rendszer kifejlesztésével a Pénzügyminisztérium már bármikor hozzáfér a KGR-K11 rendszerben szolgáltatott adatszolgáltatásokhoz, így nem szükséges minden egyes javítás után az adatszolgáltatások javított változatát, és az ezekhez kapcsolódó, származtatott információkat megküldeni részükre.

\section{KÖVETKEZTETÉSEK, JAVASLATOK}

Az államháztartás belső pénzügyi ellenőrzésén belül a költségvetési szervek előirányzat gazdálkodásában, finanszírozásában és adatszolgáltatásaik ellenőrzésében hatalmas előrelépést jelentett a 2011. évi államháztartási törvény megalkotása. Megteremtette a 
törvényi kereteket ahhoz, hogy a 2013. évi 4. számú kormányrendelet létrehozásával az államháztartási számvitelben helyet kapjon a pénzügyi számvitel, aminek folytán lehetséges lett a hasonló szerkezetű adatszolgáltatási adatbázisok létrehozása. Az adatszolgáltatások állami szinten megvalósuló egységes szerkezetének létrehozása még folyamatban van. Már felismerték, hogy az egységes szerkezetú főkönyvnek és a gyorsabb információáramlásnak köszönhetően átláthatóbb a gazdálkodás. Az informatikai megoldásokkal támogatott információs rendszerek is az adatszolgáltatás hatékonyságát növelik a teljesítés idejének rövidülésével és a rendszerbe építhető ellenőrzésekkel. Ennek köszönhetően az éves költségvetési beszámoló adatszolgáltatásai is hamarabb elkészülnek, így a zárszámadás elkészítését nem késleltetik.

A könyvelői programok sokszínűsége még mindig nagy feladatot ró mind a KGR-K11 rendszer fejlesztői, mind pedig a felhasználók számára. Ma már a rendszerhez szükséges egységes szerkezetet produkálni tudják a különböző számviteli szoftverek.

A mai napig leggyakrabban előforduló hibák mégsem a programokban keresendők, hanem a könyvelést, adatszolgáltatást végzők hiányos jogszabályismeretében. Azok az ellenőrzések, amiket a KGR-K11 rendszer el tud végezni, olyan szabályok, amelyek betartása hiányában az adatszolgáltatást teljesíteni sem tudják, hiszen ameddig egy adatszolgáltatást nem adnak fel, addig az nem tekinthető elkészültnek. Amíg a számszaki eltérések és kitöltési hiányosságok fennállnak, addig nem lehet feladott státuszú egy adatszolgáltatás. Az indoklással érintett sorok esetében is számtalanszor előfordul, hogy nem a jogszabályi elő́rások alapján létrehozott kitöltési útmutatóban meghatározottaknak megfelelően írják meg az indoklásokat. Ritkán szükséges visszautasítani egy-egy adatszolgáltatást nem megfelelő számlára történő könyvelés miatt, amit a KGR-K11 rendszer nem hivatott ellenőrizni, csak a referensek találnak rá a hibára az indoklások alapján.

A KGR-K11 rendszerből származó információkra épülő bírság modulnak köszönhetően már jól követhető, nyilvántartható a határidők betartása, valamint a rendszerbe ágyazott határozatmintákkal könnyen kiszabhatóak a szükséges bírságok, akár az ismételt szankcionálás esetén is. Sőt a rendszer képes a kivételkezelésre, vagy a tévesen hozott határozatok visszavonására is.

A riportolás lehetősége még nem megoldott a bírság modulban, mint például a különböző lekérdezések, az utalási állományok létrehozása a bírságok terhelésére a számlavezető rendszer számára, illetve a statisztikai állományok elkészítése, táblázatba foglalása elemzéshez, tájékoztatáshoz vagy a honlapra történő közzétételre.

Az adatszolgáltatások szerkezetének hasonlósága általi egyszerűsödése, átláthatósága lehetővé tette határidő megszabását az adatszolgáltatások benyújtására, illetve a fejezeti és a kincstári vizsgálatok elvégzésére. Ezen időszakok hosszának csökkenése, a javítások azonnali lehetősége nagyban lerövidítette a főkönyvvel egyező adatszolgáltatások elkészítését, s ezáltal a zárszámadáshoz szükséges, az éves költségvetési beszámolókkal alátámasztott adatszolgáltatás elvégzését. 
Az elektronikus adatszolgáltatás lehetőségének megteremtése az adatáramlást is felgyorsította, így az adatszolgáltatások teljesítésénél meg lehet követelni a határidők pontos betartását is.

Összegezve, a KGR-K11 rendszer, a rendszerbe épített, valamint a Pénzügyminisztérium által kiadott ellenőrzési szempontok szerinti ellenőrzés, a rendszerből származó adatokra épülő bírság modul bevezetése az államháztartás belső ellenőrzési rendszerébe az adatszolgáltatások pontosságát, és az ellenőrzések hatékonyságát nagymértékben megnövelte.

\section{FELHASZNÁLT IRODALOM}

ARADI Zsolt et al. (2004): Költségvetési tervezés, gazdálkodás, beszámolás, ellenőrzés, Budapest, SALDO Rt. 23. o

BENCZES István - KUTASI Gábor (2010): Költségvetési pénzügyek, Budapest, Akadémiai Kiadó

BLUMNÉ BÁN Erika - VÖRÖS László (2010): Az ellenőrzés rendszere és általános módszertana, Budapest, Saldo Zrt.

SIMON József (2012): Az államháztartási számvitel alapjai és a közpénzügyi információs rendszer, Budapest, Complex Kft.

2011. évi CXCV. tv. az államháztartásról (Áht.) 102.S (1) bekezdés

2011. évi CXCV. tv. az államháztartásról 107.S (1) bekezdés

2011. évi CXCV. tv. az államháztartásról 108.§ (1) bekezdés

2011. évi CXCV. tv. az államháztartásról 108.S (3) bekezdés, (5) bekezdés

2011. évi CXCV. tv. az államháztartásról 36.\$ (4) bekezdés

2016. évi CL. tv. az általános közigazgatási rendtartásról 114.』(1) bekezdés

2016. évi CL. tv. az általános közigazgatási rendtartásról 116.』 (1) bekezdés és (4) bekezdés a) pont

2018. évi időközi költségvetési jelentés kitöltési útmutatója a központi alrendszer számára

allamhaztartas.kormany.hu/a-hazai-allamhaztartasi-belso-kontroll-bemu

allamkincstar.gov.hu/hu/a-kincstar

az államháztartás számviteléről szóló 4/2013 (I.11,) Korm. rendelet 17. melléklet 1. pont

az államháztartás számviteléről szóló 4/2013 (I.11,) Korm. rendelet 39.\$ (1a) bekezdés

az államháztartás számviteléről szóló 4/2013 (I.11,) Korm. rendelet 9.\$ (2) bekezdés, 32.』 (1) bekezdés, 48.S (7) bekezdés, 54.§

az államháztartás végrehajtásáról szóló 368/2011 (XII.31,) Korm. rendelet 169.§, 170.S, 171.S, 172/A.§, 167/M.§ (1) bekezdés - 5. mell. 
${ }^{18}$ 这 57
BGE 